\title{
APLIKASI SISTEM AKUNTANSI DESA UNTUK PELAPORAN KEKAYAAN DAERAH PADA DESA MANDALAWANGI, BANTEN
}

\author{
Praptiningsih $^{1}$, Satria Yudhia Wijaya ${ }^{2}$, Fitri Yetty ${ }^{3}$ \\ ${ }^{1}$ Universitas Pembamgunan Nasional Veteran Jakarta, \\ ${ }^{2}$ Universitas Pembamgunan Nasional Veteran Jakarta \\ ${ }^{3}$ Universitas Pembamgunan Nasional Veteran Jakarta
}

praptiningsih@upnvj.ac.id, satria.wijaya@upnvj.ac.id, fitriyetty_61@yahoo.com ,

\begin{abstract}
Abstrak
Latar belakang Program Pengabdian Masyarakat ini dalam era reformasi pengelolaan keuangan daerah sudah mengalami berbagai perubahan regulasi dari waktu ke waktu. Perubahan tersebut merupakan rangkaian bagaimana suatu Pemerintah Daerah dapat menciptakan good governance dan clean goverment dengan melakukan tata kelola pemerintahan dengan baik. Pengelolaan keuangan daerah harus dikelola secara tertib, taat pada peraturan perundang-undangan, efektif, efisien, ekonomis, transparan, dan bertanggung jawab. bertujuan untuk meningkatkan Akuntabilitas Laporan Keuangan Desa, untuk membantu pembuatan laporan kekayaan milik desa Mandalawangi. Metode yang dilakukan dengan cara memberikan pelatihan dan pendampingan sekaligus memperkenalkan sistem akuntansi desa untuk pelaporan kekayaan Daerah di Kecamatan Mandalawangi Kabupaten Pandeglang. sistem ini tidak untuk menggantikan aplikasi milik BPKP tetapi justru akan melengkapi, dengan harapan setelah menguasai aplikasi ini maka para aparatur desa tidak hanya sebagai operator pembukuan saja tetapi diharapkan akan lebih paham dan mengerti baik alur/siklus maupun konsep dasar akuntansi desa. Luaran kegiatan ini adalah artikel ilmiah (pengelolaan) keuangan Desa serta dan Pembuatan Laporan Kekayaan Milik Desa dengan Aplikasi sistem Akuntansi. Dengan adanya sistem akuntansi desa dapat membantu penyusunan Laporan Kekayaan Milik Desa, Laporan Realisasi Anggaran Pendapatan dan Belanja Desa serta buku-buku pengawasannya sehingga akan memudahkan mereka dalam mengelola dan memelihara seluruh aset atau kekayaan desa yang dimiliki.
\end{abstract}

Kata Kunci : Aplikasi, Sistem ,Akuntansi , desa, kekayaan ,daerah

\section{PENDAHULUAN}

Desa bagian terkecil dari Negara Republik Indonesia. Desa menjadi salah satu peran terbesar dalam berkembangnya suatu negara, tentunya tanggung jawab suatu desa juga besar pula. Ismail (2016) menyatakan bahwa Negara harus mengikuti perkembangan desa atau tut wurihandayani. Hoesada (2014) menyatakan bahwa dalam pembangunan sarana desa dan dusun pada tahun yang akan datang akan meningkat secara relevan atau signifikan, pemerintah desa akan mendapat gaji dari Negara. Dalam hal ini desa sangat diistimewakan oleh pemerintah, desa mendapat bantuan dari APBN dan APBD seperti Dana desa dan alokasi Dana desa. 
Desa Mandalawangi telah melaksanakan pembukuan dalam pengelolaan Keuangannya. Saat ini pembukuan akuntansi desa Mandalawangi menggunakan sistem akuntansi yang diperoleh dari BPKP. Laporan keuangan yang dihasilkan dari sistem tersebut meliputi laporan Buku Kas, Buku Jurnal serta Laporan Realisasi Anggaran Desa, serta Laporan Kekayaan Milik Desa oleh bagian aparat desa. Temuan yang didapatkan pada saat kami melakukan Abdimas beberapa tahun lalu, bahwa Desa Mandalawangi belum membuat Laporan Kekayaan Milik Desa padahal laporan tersebut wajib dilaporkan ke Pemda. Kendala yang dihadapi pada saat itu menyatakan bahwa $\mathrm{p}$ [ sistem yang didapatkan dari BPKP belum mengakomodir penyusunan Laporan Kekayaan Milik Desa termasuk dalam hal pengawasan anggarannya sehingga kami rasa perlu bagi tim kami melengkapi untuk membuat system akuntansi yang akan membantu pengelola keuangan Desa Mandalawangi dalam menyusun Laporan Kekayaan Milik Desa.

Pengelolaan Keuangan Desa adalah keseluruhan kegiatan yang meliputi perencanaan, pelaksanaan, penatausahaan, pelaporan, dan pertanggungjawaban keuangan desa. Penyelenggaraan kewenangan Desa berdasarkan hak asal usul dan kewenangan lokal berskala Desa didanai oleh APBDesa. Penyelenggaraan kewenangan lokal berskala Desa selain didanai oleh APB Desa, juga dapat didanai oleh anggaran pendapatan dan belanja negara dan anggaran pendapatan dan belanja daerah. Penyelenggaraan kewenangan Desa yang ditugaskan oleh Pemerintah didanai oleh anggaran pendapatan dan belanja negara. Dana anggaran pendapatan dan belanja negara dialokasikan pada bagian anggaran kementerian/lembaga dan disalurkan melalui satuan kerja perangkat daerah kabupaten/ kota. Penyelenggaraan kewenangan Desa yang ditugaskan oleh pemerintah daerah didanai oleh anggaran pendapatan dan belanja daerah . Seluruh pendapatan Desa diterima dan disalurkan melalui rekening kas Desa dan penggunaannya ditetapkan dalam APB Desa. Pencairan dana dalam rekening kas Desa ditandatangani oleh kepala Desa dan Bendahara Desa. Pengelolaan keuangan Desa meliputi: perencanaan, pelaksanaan, Penatausahaan, pelaporan,dan pertanggungjawaban. Kepala Desa adalah pemegang kekuasaan pengelolaan keuangan Desa.Dalam melaksanakan kekuasaan pengelolaan keuangan Desa, kepala Desa menguasakan sebagian kekuasaannya kepada perangkat Desa.

Perubahan Peraturan Desa tentang dapat dilakukan apabila terjadi, keadaan yang menyebabkan harus dilakukan pergeseran antar jenis belanja, keadaan yang menyebabkan sisa lebih perhitungan anggaran (SilPA) tahun sebelumnya harus digunakan dalam tahun berjalan, terjadi penambahan dan/atau pengurangan dalam pendapatan desa pada tahun berjalan terjadi peristiwa khusus, seperti bencana alam, krisis politik, krisis ekonomi, dan/atau kerusuhan sosial yang berkepanjangan, perubahan mendasar atas kebijakan Pemerintah dan Pemerintah Daerah, Perubahan APBDesa hanya dapat dilakukan 1 (satu) kali dalam 1 (satu) tahun anggaran, tata cara pengajuan perubahan APBDesa adalah sama dengan tata cara penetapan APBDesa. Dalam hal Bantuan keuangan dari APBD Provinsi dan APBD Kabupaten/Kota serta hibah dan bantuan pihak ketiga yang tidak mengikat ke desa disalurkan setelah ditetapkannya Peraturan Desa tentang Perubahan APB Desa, perubahan diatur dengan Peraturan Kepala Desa tentang perubahan APBDesa.

Peraturan pelaksanaan dari UU nomor 6 tahun 2014 yang telah ada sampai dengan saat ini yaitu PP nomor 43 tahun 2014 tentang desa, PP nomor 60 tahun 2014 tentang dana desa yang bersumber dari APBN, serta beberapa aturan teknis dari kementrian dalam negeri diantaranya yaitu Permendagri nomor 113 tahun 2014 tentang Pengelolaan Keuangan Desa.

Menurut Permendagri Nomor 113 tahun 2014 tentang pengelolaan Keuangan Desa, yang berarti keseluruhan kegiatan yang meliputi perencanaan, pelaksanaan, penatausahaan , pelaporan , penatausahaan, pelaporan, dan pertanggungjawaban keuangan desa. Pemerintah daerah mempunyai tanggungjawab yang besar dalam memantau kinerja pemerintah desa di dalam pengelolaan keuangan desa tersebut. Dalam mengelola keuangan desa khususnya Dana desa 
diharapkan pemerintah desa dapat memanfaatkan potensi sumber daya alam yang dimiliki untuk memajukan dan mengembangkan desanya sendiri.

\section{Akuntansi Desa adalah pencatatan dari proses transaksi yang terjadi di desa, dibuktikan dengan nota-nota kemudian dilakukan pencatatan dan pelaporan keuangan sehingga mampu menghasilkan informasi dalam bentuk laporan keuangan yang digunakan untuk pihak- pihak yang berhubungan dengan desa (Suwarjeni, 2015)}

Pelaksanaan Aturan Umum terdiri dari semua penerimaan dan pengeluaran desa dalam rangka pelaksanaan kewenangan desa dilaksanakan melalui rekening kas desa, khusus bagi desa yang belum memiliki pelayanan perbankan di wilayahnya maka pengaturannya ditetapkan oleh Pemerintah Kabupaten/Kota, semua penerimaan dan pengeluaran desa harus didukung oleh bukti yang lengkap dan sah, pemerintah desa dilarang melakukan pungutan sebagai penerimaan desa selain yang ditetapkan dalam peraturan desa, bendahara dapat menyimpan uang dalam Kas Desa pada jumlah tertentu dalam rangka memenuhi kebutuhan operasional pemerintah desa, Pengaturan jumlah uang dalam kas desa ditetapkan dalam Peraturan Bupati/Walikota, Pengeluaran desa yang mengakibatkan beban APBD tidak dapat dilakukan sebelum rancangan peraturan desa tentang APBDesa ditetapkan menjadi peraturan desa. Pengeluaran desa sebagaimana dimaksud pada no 7 tidak termasuk untuk belanja pegawai yang bersifat mengikat dan operasional perkantoran yang ditetapkan dalam peraturan kepala desa, Penggunaan biaya tak terduga terlebih dulu harus dibuat Rincian Anggaran Biaya yang telah disahkan oleh Kepala Desa, Pengadaan barang dan/atau jasa di Desa diatur dengan peraturan bupati/walikota dengan berpedoman pada ketentuan peraturan perundang-undangan.

\section{METODE}

Metode yang digunakan dalam kegiatan ini adalah metode praktik langsung dimana materi telah disesuaikan dengan kondisi kegiatan desa seharihari. Hal ini bertujuan untuk memberikan pemahaman bagi para kepala desa, bendahara, sekretaris desa dan aparat terkait dengan keuangan desa di Kecamatan Mandalawangi Pandeglang sehingga mampu untuk menerapkan dalam pelaksanaannya, dengan kriteria dan menetapkan indikator keberhasilan sebagai berikut: 1) Pelatihan, Meningkatkan pemahaman dan pengetahuan tentang penyusunan Laporan Kekayaan Milik desa dan peserta dapat menjalankan Aplikasi Sistem akuntansi desauntuk membantu menyusun laporan keuangannya. 2) Pendampingan, peserta mampu melakukan pencatatan pada buku kas umum (BKU) dan bukubuku pembantunya. Pencatatan pada buku jurnal umum, buku besar, dan buku besar pembantu, serta penyusunan Laporan Keuangan desa termasuk Laporan Kekayaan Milik Desa.

\section{HASIL DAN PEMBAHASAN}

\section{Maintain Menu Awal Aplikasi}

Secara umum program pengabdian masyarakat ini bertujuan memberikan pelatihan dan pendampingan untuk meningkatkan profesionalisme para aparatur pemerintah Desa di Mandalawangi dalam mempelajari secara teknis ketentuan dan tata cara penatausahaan administrasi keuangan desa karena anggaran yang turun ke desa sangat besar yang harus di kelola desa sehingga diperlukan penguatan SDM terutama kepada bendahara Desa yang memang ranahnya pembuatan pelaporan sesuai aturan undang-undang yang berlaku agar menghindari kesalahan serta kerugian anggaran negara. Kegiatan ini memiliki keterkaitan yang sangat mutualis dengan pihak Badan Pemberdayaan dan Pemerintahan Desa (BPMPD) di Desa Mandalawangi, Pandeglang.

Luaran kegiatan ini adalah: Software Excel for Accounting, Panduan penatausahaan (pengelolaan) keuangan Desa serta artikel ilmiah. Adapun materi yang diberikan selama pelatihan dan pendampingan meliputi : (1) Pengetahuan dasardasar akuntansi, (2) Penatausahaan administrasi keuangan Desa dengan pokok pembahasan pelaksanaan pencatatan pada buku kas umum (BKU), buku jurnal, buku besar dan buku-buku pembantunya, (3) Pelatihan Software Sistem akuntansi desauntuk menyusun Laporan Kekayaan Milik Desa. Berikut ini tahapan yang ingin dicapai dapat dijabarkan dapat tabel berikut. 


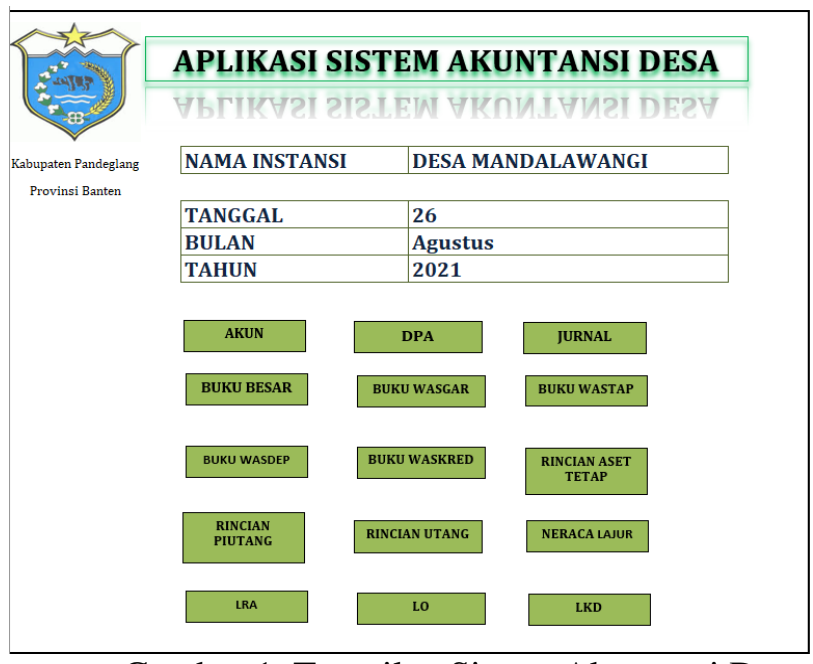

Gambar 1. Tampilan Sistem Akuntansi Desa

Menu awal program terdiri dari : Nama Instansi, tanggal, bulan dan tahun periode pembukuan, serta tampilan sembilan menu yaitu : Akun, DPA, Jurnal, Buku Besar, Buku Wasgar, Neraca Lajur, LRA, LO, dan Laporan Kekayaan Milik Desa (LKMD).

\section{Akun}

Pada menu akun ini memuat kode, akun, nama akun serta saldo akun yang akan digunakan untuk melakukan pembukuan akuntansi desa, semua dimaintain pada menu ini.

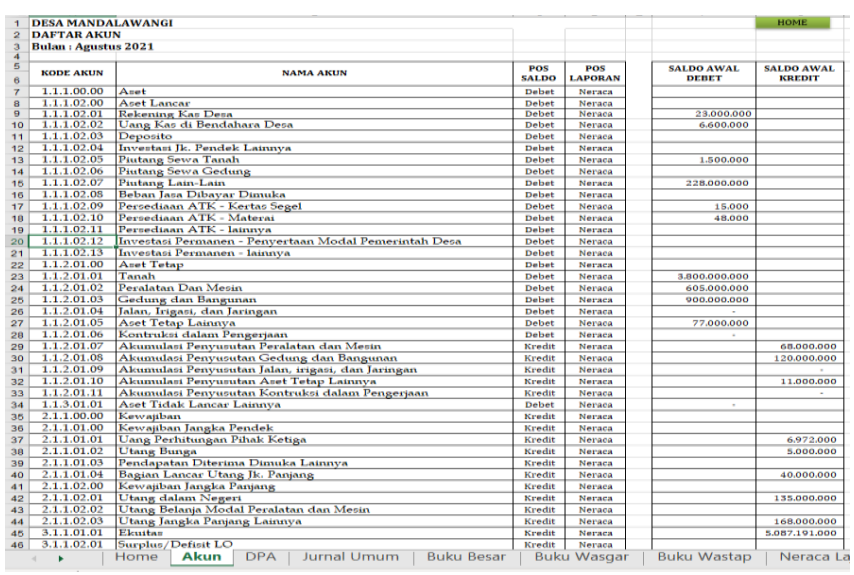

Gambar 2. Daftar Akun

\section{Daftar Proyek Anggaran (DPA)}

DPA ini untuk mencatat daftar anggaran desa pada periode berjalan, serta sebagai acuan untuk mengawasi pagu anggaran desa

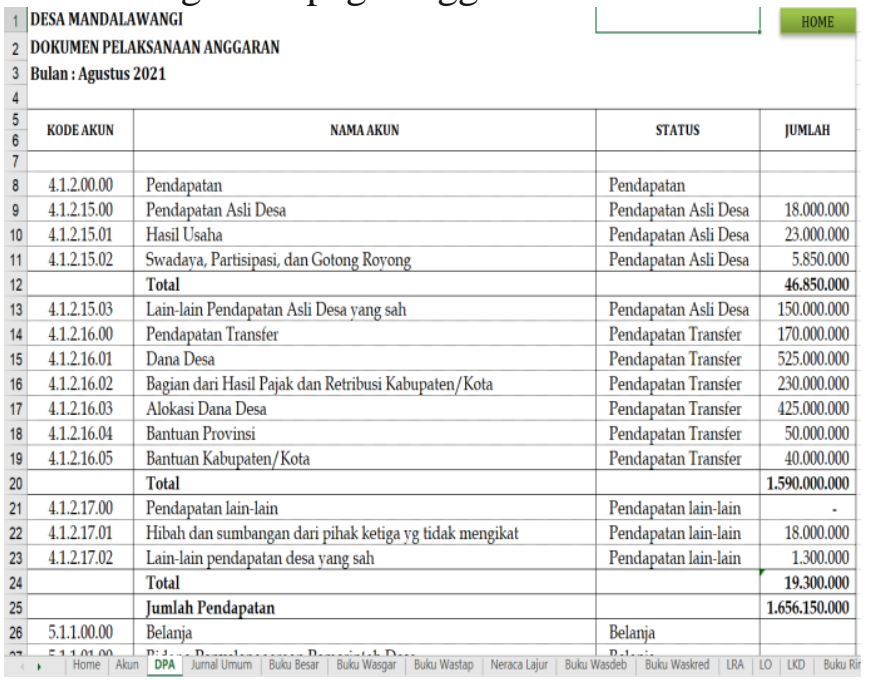

Gambar 3. Daftar Pelaksanaan Anggaran

\section{Buku Besar}

Buku besar berfungsi untuk merekap semua transaksi dari masing-masing akun tersebut sebagai dasar membuat laporan Neraca Lajur.

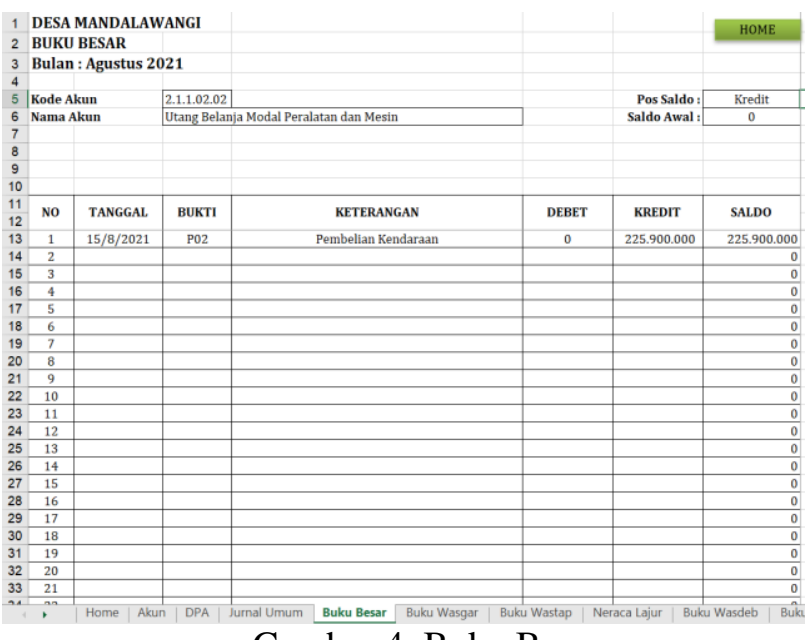

Gambar 4. Buku Besar

\section{Neraca Lajur}

Neraca lajur berfungsi untuk merekap semua laporan serta saldo dari masing-masing akun. 


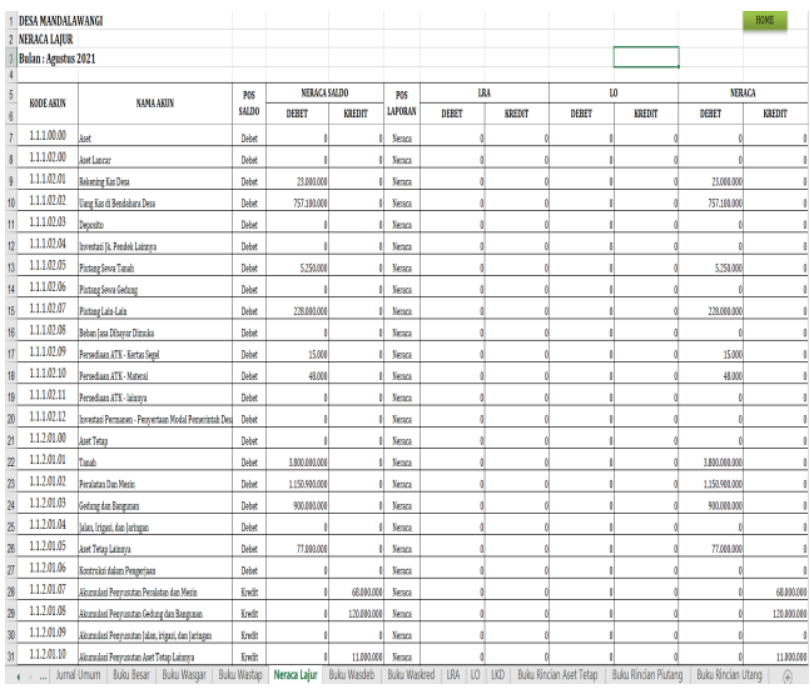

Gambar 5. Neraca Lajur

\section{Laporan Realisasi Anggaran}

Merupakan Laporan Realisasi Anggaran atas Pelaksanaan Anggaran dalam periode berjalan, pada laporan ini dapat terlihat persentase sisa anggaran yang belum terserap.

\begin{tabular}{|c|c|c|c|c|c|}
\hline \multicolumn{6}{|l|}{1} \\
\hline \multicolumn{6}{|c|}{2 DESA MANDALAWANGI } \\
\hline \multicolumn{6}{|c|}{3 LAPORAN REALISASI ANGGARAN PENDAPATAN DAN BELANJA DESA } \\
\hline \multirow{2}{*}{\multicolumn{6}{|c|}{$\begin{array}{l}4 \text { Bulan: Agustus } 2021 \\
5\end{array}$}} \\
\hline & & & & & \\
\hline \multicolumn{6}{|l|}{6} \\
\hline 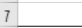 & & & & & \\
\hline $\begin{array}{ll}8 & \text { KODE } \\
9 & \text { AKUN }\end{array}$ & NAMA AKUN & PAGU & REALISASI & SISAPAGU & $\begin{array}{c}\% \% \\
\text { PENYERAPAN }\end{array}$ \\
\hline \multicolumn{6}{|l|}{10} \\
\hline$1 1 \longdiv { 4 . 1 . 2 0 0 0 . 0 0 }$ & Pendapatan & & & & \\
\hline$1 2 \longdiv { 4 . 1 . 2 1 5 . 0 0 }$ & Pendapatan Asli Desa & 18.000 .000 & . & 18.000.000 & . \\
\hline 134.1 .215 .01 & Hasil Usaha & 23.000 .000 & & 23.000 .000 & . \\
\hline$1 4 \longdiv { 4 . 1 . 2 1 5 . 0 2 }$ & Swadaya, Partisipasi, dan Gotong Royong & 5.850 .000 & 19.000.000 & -13.150 .000 & 325 \\
\hline$1 5 \longdiv { 4 . 1 . 2 1 . 2 5 0 3 }$ & Lain-lain Pendapatan Asli Desa yang sah & 150.000 .000 & 25.000.000 & 125.000 .000 & 17 \\
\hline$1 6 \longdiv { 4 . 1 . 2 1 6 . 0 0 }$ & Pendapatan Transfer & 170.000 .000 & 6.500 .000 & 163.500 .000 & 4 \\
\hline 174.1 .216 .01 & Dana Desa & 525000.000 & . & 525.000 .000 & . \\
\hline$1 8 \longdiv { 4 . 1 . 2 1 6 . 0 2 }$ & Bagian dari Hasil Pajak dan Retriluusi Kaburpaten/Kota & 230.000 .000 & 550.000 .000 & -320.000 .000 & 239 \\
\hline$1 9 \longdiv { 4 . 1 . 2 1 6 . 0 3 }$ & Alokasi Dana Desa & 425.000 .000 & 300.000 .000 & 125.000 .000 & 71 \\
\hline$2 0 \longdiv { 4 . 1 . 2 1 6 . 0 4 }$ & Bantuan Provinsi & 50.000 .000 & . & 50.000 .000 & . \\
\hline$2 1 \longdiv { 4 . 1 . 2 1 6 . 0 5 }$ & Banturan Kabupaten/Kota & 40.000 .000 & . & 40.000 .000 & . \\
\hline$2 2 \longdiv { 4 . 1 2 1 7 . 0 1 }$ & Hilah dan sumbangan dari pihak ketiga yg tidak mengikat & 18.000 .000 & . & 18.000 .000 & . \\
\hline$2 3 \longdiv { 4 . 1 . 2 1 7 . 0 2 }$ & Lain-lain pendapatan desa yang sahh & 1.300 .000 & . & 1.300 .000 & . \\
\hline 24 & Jumlah Pendapatan & 1.656 .150 .000 & 900.500 .000 & & \\
\hline 2555.1 .100 .00 & Belanjia & & & & \\
\hline 26 5.1.1.01.01 & Penghasilan Tetap dan Tunjinngan- Belanija Pegawaii & 360.000 .000 & . & 360.000 .000 & - \\
\hline 27 5.1.1.01.02 & Operasional Perkantoran- Belanjia Barang dan Jasa & 24000.000 & . & 24.000.000 & - \\
\hline 28 5.1.1.01.03 & Operasional Perkantoran - Belanija Moddal & 50.000 .000 & . & 50.000 .000 & . \\
\hline 29 5.1.1.01.04 & Operasional BPD - Belanja Barang dan Jasa & 12000.000 & . & 120000000 & - \\
\hline 30 5.1.1.01.05 & Operasional RT/RW - Belania Barang dan Jasa & 144.000.000 & . & 144.000.000 & - \\
\hline 315.1 .215 .01 & Perbaikan saluran irigasi- Belanja barang dan jaca & 75.000 .000 & . & 75.000 .000 & - \\
\hline 325.1 .215 .02 & Pertbaikan saluran irigasi - Belannia modal & 150.000 .000 & . & 150.000 .000 & . \\
\hline 1 Ho & ve Akun DPA Jumal Umum Buku Besar Buka Wasgar Bu & Neroca Lajur & Bulu Wasdeb $B$ & Jiku Wasked LRA & 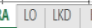 \\
\hline
\end{tabular}

Gambar 6. Laporan Realisasi Anggaran

\section{Laporan Operasional}

Laporan Operasional (LO) dimana pada laporan ini dapat terlihat jumlah pendapatan dan beban pada periode berjalan, sehingga dapat terlihat surplus minus dari kegiatan dalam satu periode berjalan.

\begin{tabular}{|c|c|c|c|}
\hline \multicolumn{3}{|c|}{2 DESA MANDALAWANGI } & \multirow[t]{2}{*}{ HOME } \\
\hline 3 & \multirow{2}{*}{\multicolumn{2}{|c|}{$\begin{array}{l}\text { LAPORAN OPERASIONAL } \\
\text { Bulan : Agustus } 2021\end{array}$}} & \\
\hline 4 & & & \\
\hline 6 & & \multirow[b]{2}{*}{ NAMA AKUN } & \multirow[b]{2}{*}{ NOMINAL } \\
\hline 7 & AKUN & & \\
\hline \multicolumn{4}{|l|}{8} \\
\hline 9 & 7.1 .2 .00 .00 & Pendapatan - LO & 0 \\
\hline 10 & 7.1 .2 .15 .00 & Pendapatan Asli Desa & 0 \\
\hline 11 & 7.1.2.15.01 & Hasil Usaha & 19.000 .000 \\
\hline 12 & 7.1.2.15.02 & Swadaya, Partisipasi, dan Gotong Royong & 25.000 .000 \\
\hline 13 & 7.1.2.15.03 & Lain-lain Pendapatan Asli Desa yang sah & 10.250 .000 \\
\hline 14 & 7.1.2.16.00 & Pendapatan Transfer & 0 \\
\hline 15 & 7.1.2.16.01 & Dana Desa & 550.000 .000 \\
\hline 16 & 7.1.2.16.02 & Bagian dari Hasil Pajak dan Retribusi Kabupaten/Kota & 0 \\
\hline 17 & 7.1.2.16.03 & Alokasi Dana Desa & 0 \\
\hline 18 & 7.1.2.16.04 & Bantuan Provinsi & 0 \\
\hline 19 & 7.1.2.16.05 & Bantuan Kabupaten/Kota & 0 \\
\hline 20 & 7.1.2.17.00 & Pendapatan lain-lain & 0 \\
\hline 21 & 7.1.2.17.01 & Hibah dan sumbangan dari pihak ketiga yg tidak mengikat & 0 \\
\hline 22 & 7.1.2.17.02 & Lain-lain pendapatan desa yang sah & 0 \\
\hline & Home & 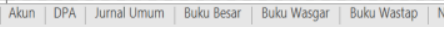 & \begin{tabular}{l|l} 
Buku Wasdeb & Buk
\end{tabular} \\
\hline
\end{tabular}

Gambar 7. Laporan Operasional

\section{Laporan Kekayaan Desa (LKD)}

LKD diana pada laporan ini dapat terlihat jumlah Aset, utang serta modal desa serta komposisinya masing-masing sehingga dapat tergambarkan kekuatan keseluruhan potensi desa yang saat ini dimiliki.

\begin{tabular}{|c|c|c|c|c|}
\hline \multicolumn{5}{|l|}{1} \\
\hline 2 & \multicolumn{2}{|c|}{ DESA MANDALAWANGI } & & HOME \\
\hline 3 & \multicolumn{2}{|c|}{ LAPORAN KEKAYAAN DESA } & & \\
\hline 4 & \multicolumn{2}{|c|}{ Tanggal : 26 Agustus 2021} & & \\
\hline \multicolumn{5}{|l|}{5} \\
\hline $\begin{array}{l}6 \\
7\end{array}$ & KODE AKUN & NAMA AKUN & JUMLAH & TOTAL \\
\hline \multicolumn{5}{|l|}{8} \\
\hline 9 & 1.1 .1 .00 .00 & Aset & $\cdot$ & \\
\hline 10 & 1.1.1.02.00 & Aset Lancar & $\cdot$ & \\
\hline 11 & 1.1.1.02.01 & Rekening Kas Desa & 23.000 .000 & \\
\hline 12 & 1.1.1.02.02 & Uang Kas di Bendahara Desa & 757.100 .000 & \\
\hline 13 & 1.1.1.02.03 & Deposito & $\cdot$ & \\
\hline 14 & 1.1.1.02.04 & Investasi Jk. Pendek Lainnya & $\cdot$ & \\
\hline 15 & 1.1.1.02.05 & Piutang Sewa Tanah & 5.250 .000 & \\
\hline 16 & 1.1.1.02.06 & Piutang Sewa Gedung & $\cdot$ & \\
\hline 17 & 1.1.1.02.07 & Piutang Lain-Lain & 228.000 .000 & \\
\hline 18 & 1.1.1.02.08 & Beban Jasa Dibayar Dimuka & $\cdot$ & \\
\hline 19 & 1.1.1.02.09 & Persediaan ATK - Kertas Segel & 15.000 & \\
\hline 20 & 1.1.1.02.10 & Persediaan ATK - Materai & 48.000 & \\
\hline 21 & & Jumlah Aktiva Lancar & & 1.013 .413 .000 \\
\hline \multicolumn{5}{|l|}{22} \\
\hline 22 & , $111 \mathrm{~m} 11$ & 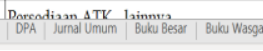 & Lajur | Buku Warde & Buke Wasked LRA LO \\
\hline
\end{tabular}

Gambar 8. Laporan Kekayaan Desa 
Berdasarkan penjabaran di atas, aplikasi Sistem Akuntansi Desa sangat dibutuhkan bagi tingkat pedesaan untuk mengetahui kekayaan desa sebagai asset yang dimiliki pedesaan dapat diketahui secara terinci dari akun yang tersedia dalam aplikasi tersebut. Laporan Kekayaan Milik Desa ini sangatlah penting karena melalui laporan ini dapat menggambarkan seluruh kekuatan dan kelemahan serta potensi Desa melalui gambaran posisi sumber daya yang dimilikinya. Untuk mempermudah pemahaman serta dasar-dasar pengetahuan kepada aparat desa terkait serta untuk membantu penyusunan Laporan Kekayaan Milik Desa khususnya serta Laporan Keuangan Desa pada umumnya, maka kami memperkenalkan Aplikasi Sistem Akuntansi Desa yang khusus dibuat untuk mempermudah dalam menyusun Laporan Keuangan Desa, mulai dari Laporan Realisasi APBDes, Laporan Operasional, sampai dengan Laporan Kekayaan Milik Desa termasuk buku-buku pengawasannya. Sistem ini bukanlah software untuk menggantikan software yang sudah ada melainkan sebagai pelengkap agar aparat desa lebih mudah dalam menyusun laporan keuangannya. Berikut foto kegiatan yang dilakukan selama melakukan penyuluhan dan pendampingan di Desa Mandalawangi, Pandeglang, Banten.

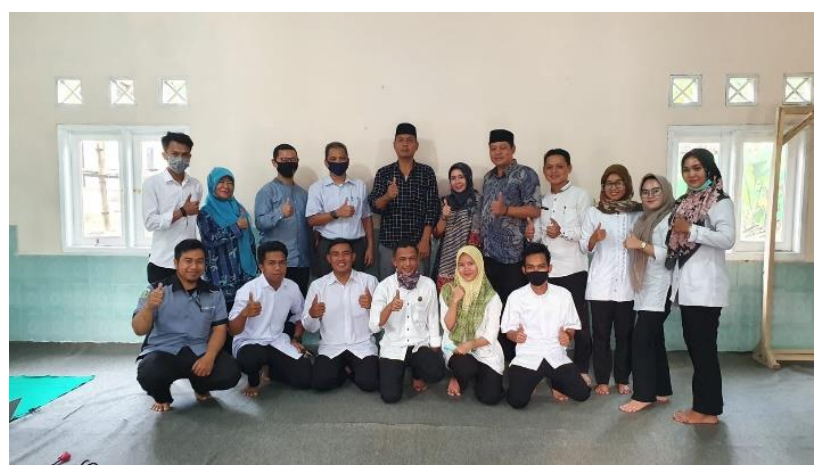

Gambar 9. Foto dengan Aparat Desa Mandalawangi

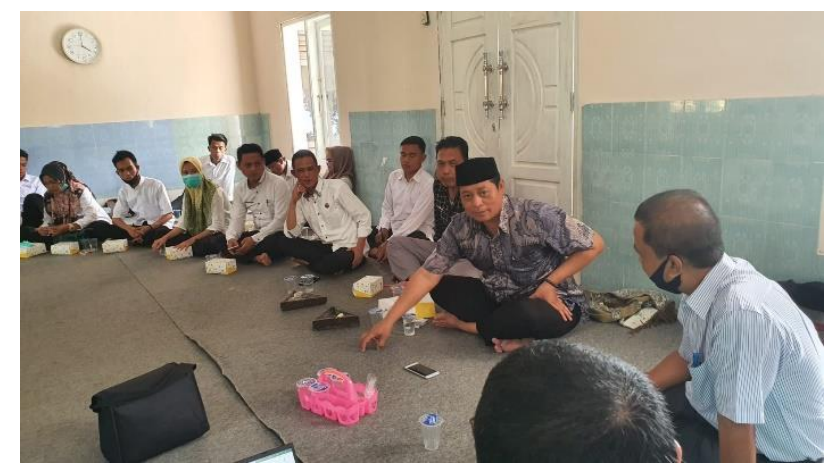

Gambar 10. Penyuluhan dan Pendampingan kepada Aparat Desa

\section{KESIMPULAN}

Salah satu bentuk Akuntabilitas desa terletak dari sejauh mana pemerintah desa tersebut mampu membuat laporan keuangan desa secara benar, konsisten dan tepat waktu sesuai dengan peraturan perundang-undangan yang berlaku. Namun hal ini bukanlah perkara mudah mengingat sumber daya manusia yang terbatas sehingga perlu dilakukan sosialisasi, penyuluhan pelatihan bahkan pendampingan untuk mewujudkan cita-cita tersebut. Melalui kegiatan abdimas ini diharapkan mampu untuk menutup segala kekurangan yang selama ini dialami oleh pemerintah desa dalam menyusun laporan keuangannya. Mengapa perlu diperkenalkan aplikasi ini, karena aplikasi ini sangat mudah digunakan, dan dipahami. Motivasi kami bahwa seseorang yang menginput ke dalam software akuntansi harus paham mengapa transaksi dan angka tersebut harus diinput, bagaimana cara meninputnya sehingga dapat melahirkan laporan dan bagaimana dampaknya terhadap laporan keuangan. Sehingga nantinya semua orang yang meninput transaksi ke dalam software dapat memahami, menjelaskan, serta menginterpretasikan semua angka yang ada pada akun-akun dalam laporan keuangan. Ibarat orang yang sedang membuat kue bolu dapat menjawab setiap pertanyaan mengenai bagaimana cara/proses pembuatan kue bolu sehingga rasanya dapat menjadi lezat seperti ini.

Kebanyakan dari software akuntansi yang beredar sekarang ini memang sekilas lebih mudah digunakan, tampilannya lebih menarik dan lebih memanjakan penggunanya karena untuk 
membukukan suatu transaksi keuangan user tidak perlu belajar lagi tentang dasar-dasar akuntansi, cukup dengan mengiput bukti-bukti yang ada ke dalam software sehingga jadilah laporan keuangan. Tentu saja bukan itu yang kami harapkan. Idealnya bagi kami bahwa setiap orang yang menginput transaksi-transaksi keuangan termasuk dengan menggunakan software akuntansi harus paham tentang akuntansi minimal dasar-dasarnya, sehingga apabila timbul pertanyaan baik itu oleh auditor maupun manajemen tentang angka-angka yang terdapat pada akun-akun dalam laporan keuangan dapat dijawab secara teknis. Atas dasar itulah alasan mengapa Software ini cukup penting untuk diperkenalkan. Dan menurut pendapat kami kemampuan tentang teknis tersebut tidak hanya ditujukan kepada pemerintahan Desa saja tetapi dapat dikembangkan kepada pengelola keuangan baik Pemerintah pusat maupun daerah, serta Kementerian dan Lembaga Pemerintah lainnya.

\section{UCAPAN TERIMAKASIH}

Ucapan terimakasih disampaikan kepada UPN Veteran Jakarta yang telah mendukung pengabdian kepada masyarakat, untuk desa Mandalawangi yang telah memberikan dukungan

\section{REFERENSI}

Enterprise, J. , 2020. Mengatur Akuntansi Kas Desa dengan MS excel. PT. Elex Media Kompetindo Jakarta

Hoesada, J. 2014. Komite standar akuntansi pemerintah (KSAP). Jakarta

Ismail, M. Widagdo, A., K. dan Widodo, A. 2016. Sistem Akuntansi Pengelolaan Dana Desa, Jurnal Eknomi dan Bisnis, 19(2): 323-340.

PP No. 43 Tahun 2014 tentang Peraturan Pelaksanaan UU No. 6 tahun 2014 tentang Desa.

PP No. 60 Tahun 2014 tentang Dana Desa Yang Bersumber Dari APBN.

PP No. 71 Tahun 2010 tentang Standar Akuntansi

\section{Pemerintahan.}

PP No. 8 Tahun 2006 tentang Pelaporan Keuangan dan Kinerja Instansi Pemerintah.

Peraturan Menteri Dalam Negeri RI No. 113 Tahun 2014 : Pengelolaan Keuangan Desa.

Undang-Undang Nomor 6 Tahun 2014 tentang Desa.

Undang-undang Nomor 17 Tahun 2003 tentang Keuangan Negara.

Undang-undang Nomor 1 Tahun 2004 tentang Perbendaharaan Negara.Ganjar, Isnawan, 2012, Akuntansi Praktis Untuk UMKM, Penerbit: Laskar Aksara, Jakarta

Sujarweni, V., M. 2019. Akuntansi Desa Pedoman Tata Kelola Keuangan Desa. Pustaka Baru Press. . Pustaka Baru Press. Yogyakarta. 